\title{
Prototype E-Katalog Dan Peminjaman Buku Perpustakaan Berbasis Mobile
}

\author{
Vivi Sahfitri \\ Program Studi Manajemen Informatika \\ Universitas Bina Darma, Indonesia \\ e-mail : vivi_sahfitri@binadarma.ac.id
}

\begin{abstract}
Abstrak-Pepustakaan dapat diartikan sebagai kumpulan informasi yang berkaitan dengan Ilmu Pengetahuan, Hiburan, Rekreasi dan Ibadah yang merupakan salah satu kebutuhan hidup manusia agar tidak tertinggal dalam memperoleh informasi sehingga dapat berinteraksi secara aktif dengan manusia lain sebagai mahkluk sosial. Penelitian ini bertujuan untuk membangun prototype Katalog dan peminjaman buku perpustakaan berbasis mobile yang mampu memberikan informasi tentang katalog buku yang ada diperpustakaan, informasi ketersediaan buku tersebut diperpustakaan dan mendaftarkan diri untuk meminjam buku yang diinginkan yang dilakukan secara mobile. Metode penelitian yang digunakan adalah Metode Development Research yaitu suatu kegiatan penelitian yang bertujuan dan berusaha mengembangkan atau melengkapi pengetahuan yang sudah ada atau diketahui. Penelitian ini menghasilkan Permodelan Sistem secara visual menggunakan Unified Modeling Language (UML), Rancangan Basis Data, serta Prototipe yang menghasilkan gambaran lengkap siste, yang dapat digunakan untuk mengatasi permasalah yang terjadi.
\end{abstract}

Kata Kunci-Katalog Buku, Peminjaman Buku, Prototype Sistem, Mobile

\section{PENDAHULUAN}

Berkembangnya Ilmu Pengetahuan dan teknologi informasi yang sangat pesat saat ini telah memberikan banyak manfaat diberbagai bidang Kehidupan. Dengan Teknologi Informasi yang tersedia, manusia bisa memperoleh berbagai kemudahan baik dalam memperoleh informasi secara luas melalui teknologi jaringan internet, membantu mempermudah kegiatan yang berkaitan dengan pekerjaan memalui berbagai aplikasi yang dapat diperoleh dan dinikmati dari perkembangan Teknologi Informasi dan Komputer yang begitu pesat saat ini. Salah satu kegiatan yang dapat memanfaatkan fasilitas yang diberikan oleh kemajuan Teknologi Informasi adalah kegiatan perpustakaan.

Perpustakaan adalah suatu unit kerja dari lembaga pendidikan yang berupa tempat untuk mengumpulkan, menyimpan, mengelola, dan mengatur koleksi bahan pustaka baik yang tertulis, tercetak maupun grafis lainnya [1]. Pada perguruan tinggi, perpustakaan dapat dikatakan sebagai jantung Peguruan Tinggi. Hal ini dikaitkan dengan tugas utama dosen sebagai pengajar di tingkat pendidikan tinggi yang memiliki tugas utama Tri Darma Perguruan Tinggi yang didalamnya terdapat unsur Pendidikan dan Pengajaran, Penelitian dan Pengabdian pada Masyarakat [2]. Perpustakaan dapat diartikan sebagai koleksi buku dan majalah baik secara perorangan maupun yang dibiayai dan dioperasikan oleh pemerintah maupun oleh institusi dan dimanfaatkan oleh masyarakat yang membutuhkannnya sebagai sumber informasi. Perpustakaan harus mampu berperan sebagai learning Centre, sehingga perpustakaan tidak sebatas pada aktivitas sirkulasi koleksi perpustakaan namun juga harus mampu memfasilitasi aktivitas social lainnya [3]. Banyaknya buku ataupun majalah yang menjadi koleksi sebuah perpustkaan mengakibatkan sebuah perpustakaan harus memiliki katalog yang dapat memberikan informasi buku buku yang dimiliki oleh perpustkaan tersebut. Katalog adalah buku yang berisi daftar atau informasi yang disusun secara teratur dan berurutan secara alpabetis [4]. Katalog dapat juga diartikan sebagai suatu daftar dan indeks ke suatu koleksi buku dan bahan lainnya. Katalog memungkinkan pengguna untuk menemukan suatu bahan pustaka yang tersedia dalam koleksi perpustakaan tertentu Katalog juga memungkinkan pengguna untuk mengetahui dimana suatu bahan pustaka bias ditemukan. Dengan demikian katalog adalah suatu srana untuk menemubalikkan suatu bahan pustaka dari koleksi suatu perpustakaan [5]. Istilah Temu kembali informasi yang salah satu contohnya adalah adalah Temu kembali bahan pustaka merupakan istilah yang mengacu pada temu kembali dokumen, sumber atau data yang dimiliki unit informasi salah satunya adalah perpustakaan [6].

Perkembangan Teknologi berbasis mobile saat ini semakin pesat. Dengan adanya Teknologi mobile yang menggunakan perangkat smartphone, seseorang dapat saling terhubung dengan orang lainnya untuk saling berinteraksi, bertukar informasi ataupun sekedar memperoleh hiburan melalui berbagai aplikasi yang dapat dijalankan melalui perangkat smartphone. Berdasarkan hasil survey yang dilakukan oleh Asosiasi Penyelenggara Jasa Internet Indonesia (APJII) tentang perangkat yang digunakan untuk browsing pengguna internet di Indonesia dapat diketahui bahwa $67,8 \%$ pengguna Internet menggunakan smartphone, 14,7\% Pengguna Internet menggunakan Komputer PC, $12,6 \%$ pengguna internet menggunakan Laptop, dan $3,8 \%$ pengguna internet

ISSN : 2301-7988

E-ISSN : 2581-0588

DOI : $10.32736 /$ sisfokom.v8i2.665 
menggunakan Tablet [7]. Trend penggunaan Internet untuk grafik peningkatan penggunaan Mobile dibandingkan dengan desktop dapat diketahui penggunaan perangkat mobile paling banyak digunakan. [8].

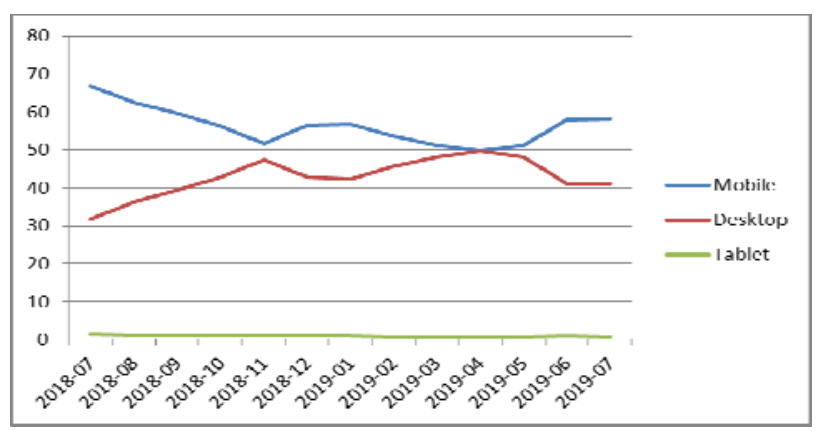

Gambar 1. Peningkatan penggunaan perangkat mobile dibandingkan dengan desktop di Indonesia

Sedangkan Sistem Operasi (OS) yang digunakan oleh pengguna smartphone, berdasarkan Laporan survey pengguna Smartphone di Amerika Serikat diketahui bahwa 51\% pengguna Smartphone menggunakan system Operasi Android sedangkan diurutan ke dua adalah system Operasi Apple IOS [9]. Sedangkan di Indonesia Sistem Operasi yang paling banyak digunakan oleh Pengguna smartpone adalah Sistem Operasi Android berdasarkan data dari Juli 2018 sampai dengan Juli 2019 [8].

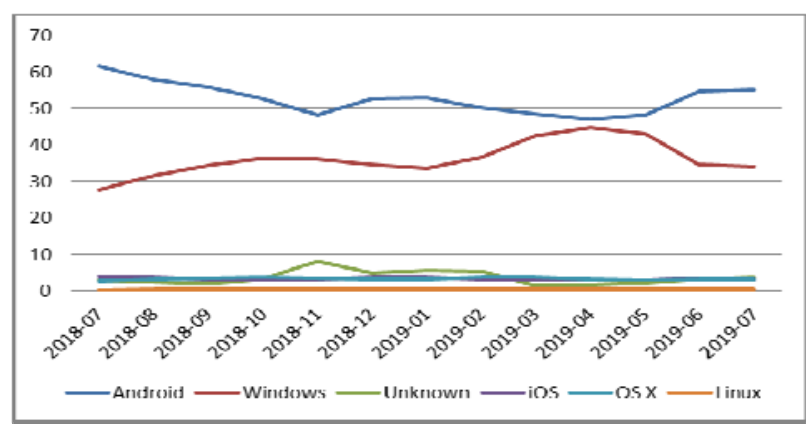

Gambar 2. Grafik penggunaan Sistem Operasi di Indonesia

Android merupakan sebuah sistem operasi yang digunakan perangkat mobile berbasis Linux, mencakup sistem operasi, middleware dan aplikasi [10]. Android merupakan generasi baru platform mobile, platform yang memberikan pengembang untuk melakukan pengembangan sesuai dengan yang diharapkannya. Android didistribusikan di bawah Lisensi Apache Software (ASL/Apache2), yang memungkinkan untuk distribusi kedua dan seterusnya. Banyak peralatan tanpa kabel atau Perangkat Nirkabel menggunakan Sistem Operasi Android, seperti tablet, netbook dan set-top box [11]. Perkembangan perangkat smartphone terutama yang berbasis Android memberikan peluang untuk memudahkan akses katalog perpustakaan dan proses peminjaman buku secara online dengan merancang aplikasi yang dapat mempermudah pencarian informasi ketersediaan buku diperpustakaan, membooking buku yang ingin dipinjam tanpa perlu datang langsung keperpustakaan.

\section{METODOLOGI PENELITIAN}

Metode penelitian merupakan langkah-langkah atau tahapan yang dilakukan dalal rangka untuk mengumpulkan informasi atau data serta melakukan investigasi pada data yang telah didapatkan tersebut.

\section{A. Metode Pengembangan Sistem}

Penelitian ini bertujuan untuk merancang suatu sistem $e$ catalog dan dan peminjaman buku berbasis Mobile untuk meningkatkan pelayanan kepada para pengguna perpustakaan. Salah satu metode pengembangan sistem yang dapat digunakan sebagai solusi dalam merancang suatu Sistem Informasi adalah Metode Prototyping. Metode Prototyping merupakan sebuah paradigma baru dalam pengembangan sistem dan aplikasi, tidak hanya sekedar suatu evolusi dari metode pengembangan sistem informasi yang sudah ada, tetapi sekaligus merupakan revolusi dalam pengembangan sistem informasi [12].

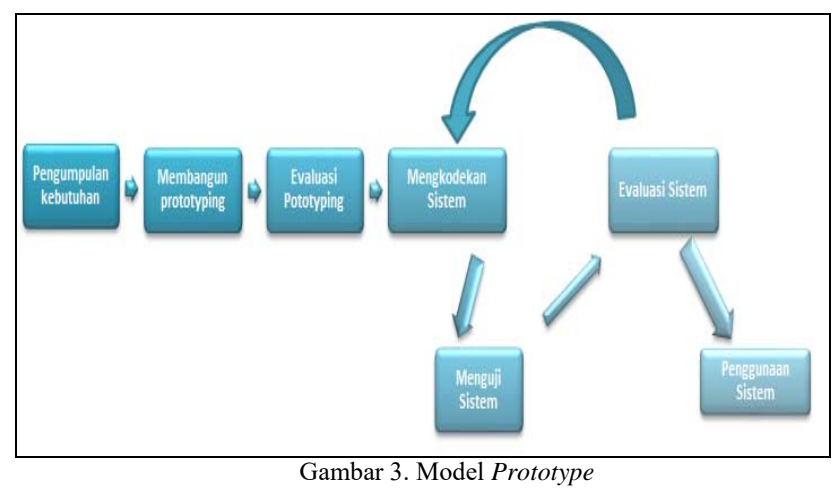

Tahapan dalam prototyping terdiri dari [12];

1) Pengumpulan kebutuhan, pada tahap ini Pelanggan dan pengembang bersama-sama mendefiniskan format dan kebutuhan perangkat lunak secara keseluruhan, mengidentifikasikan semua kebutuhan, dan garis besar sistem yang akan dibuat,

2) Membangun prototyping, yang dilakukan pada tahap ini adalah membuat desain sementara yang berpusat pada penyajian kepada pelanggan, misalnya; dengan membuat contoh input dan output,

3) Evaluasi prototyping, jika prototype yang sudah dibangun sesuai dengan keinginan pelanggan maka dilakukan evaluasi. Jika sudah sesuai akan dilanjutkan ketahap pengkodean (coding) namun jika belum sesuai maka akan diperbaik dengan mengulang kembali tahap 1,tahap 2 dan tahap 3 ,

4) Mengkodekan Sistem, tahap ini lakukan jika prototype yang dibuat sudah diterima dan disepakati yang dilanjutkan dengan pengkodean dengan bahasa pemrograman yang sesuai,

5) Menguji Sistem, tahap ini dilakukan untuk mengetahui performance dari sistem yang dibangun. Pengujian sistem dilakukan dengan metode Black Box, 
6) Evaluasi Sistem, tahap ini dilakukan untuk mengetahui apakah sistem yang dibangun telah sesuai dengan yang diharapkan. Jika sudah memenuhi dapat dilakukan tahap selanjutnya, namun jika tidak maka perlu dilakukan pengulangan pada tahap 4 dan tahap 5 ,

7) Menggunakan Sistem, yaitu sistem yang dibangun siap digunakan oleh pelanggan setelah tahap pengujian berhasil dan diterima oleh pelanggan.

Dalam penelitian ini tahapan prototype hanya dilakukan samapai dengan tahap ke-empat, karena dalam penelitian ini pelaksanaan penelitian sampai dengan pembuatan prototype sistem yang menghasilkan Prototype Sistem Informasi ekatalog dan peminjaman buku perpustakaan. Tahap pengujian belum dilakukan dala penelitian ini baik pengujian sistem ataupun dari pengguna (user).

\section{B. Penelitian Terdahulu}

Penelitian yang berkaitan dengan pembuatan e-katalog sudah cukup banyak dilakukan. Berikut ini beberapa penelitian yang berkaitan dengan e-katalog baik berbasis mobile maupun berbasis Web.

Penelitian dengan judul Merancang e-katalog berbasis Website sebagai media informasi pada Badan Perpustakaan Arsip dan Dokumentasi Daerah (BPAD) yang dilakukan oleh Deppi Linda. Penelitian ini menghasilkan rancangan e-katalog pada Badan Perpustakaan Daerah Lampung yang diharapkan dapat memberikan kemudahan dalam pengelolaan persediaan buku dan informasi publikasi yang tersedia di Perpustakaan tanpa harus mendatangi perpustakaan . Perancangan e-katalog menggunakan adobe Dreamwever CS6, MYSQL [13]. Penelitian lain berjudul Aplikasi Mobile Perpustakaan Sekolah yang dilakukan oleh Riche Cynthia Johan, Hana Silvana dan Holin Sulistyo. Penelitian ini mengembangkan prototype aplikasi mobile yang menyajikan menu yang dirancang untuk memudahkan penelusuran dan pemanfaatan Online Public Access Catalog yang dikemas dalam SLimS Online Perpusataaan Sekolah Dasar [14]. Penelitian yang dilakukan oleh Rangga Firdaus, Dwi Sakethi, dan Firdaus Rosman dengan judul Rancang Bangun Sistem Informasi Perpustakaan Berbasis Web. Penelitian ini menghasilkan Sistem Informasi Perpustakaan yang dibangun dengan menerapkan metode prototype dan bahasa pemrograman PHP MYSQL. Aplikasi yang dirancang dapat menampilkan informasi tentang data buku perpustakaan baik yang tersedia maupun yang masih dalam peminjaman [15].

\section{HASIL DAN PEMBAHASAN}

Penelitian ini menghasilkan prototype yang memberikan gambaran lengkap system e-katalog dan peminjaman buku perpustakaan berbasi mobile. Tahapan penting yang dilakukan dalam pembuatan Prototype adalah Perancangan Sistem dan Basis data serta Perancangan antar muka (interface), dimana proses tersebut harus disesuaikan dengan kebutuhan dan kemampuan pengguna sistem nantinya sehingga Perangkat lunak atau System yang dibangun akan dapat berjalan dengan baik sesuai dengan fitur dan fungsi yang diharapkan [16].

\section{A. Perancangan Sistem}

Perancangan sistem dilakukan untuk menggambarkan proses yang terjadi dalam sistem yang akan dibangun. Tahapan ini dilakukan untuk memberikan spesifikasi, merancangan, membuat model serta mendokumentasikan aspek-aspek dari sebuah aplikasi dengan menggunakan Diagram Unified Modelling Language (UML) yang terdiri dari; Use Case Diagram, Activity Diagram dan Class Diagram.

\section{1) Use Case Diagram}

Mendeskripsikan interaksi yang terjadi antara satu atau lebih aktor dengan sistem yang akan dibangun secara rinci.

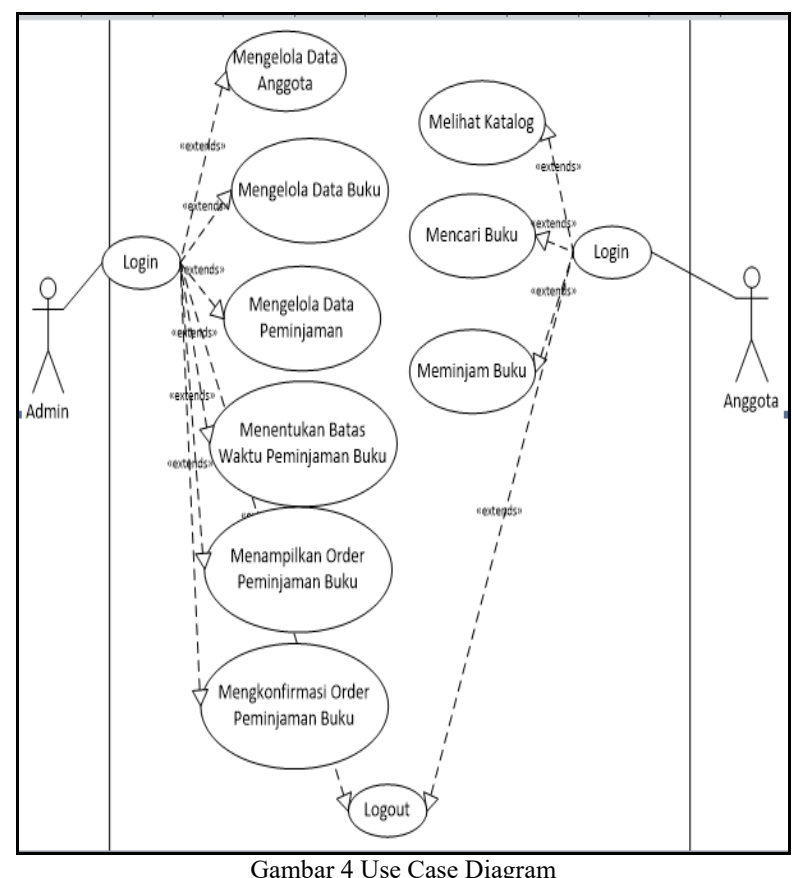

Gambar 4 menunjukan rancangan use case diagram prototype Sistem untuk e-katalog dan peminjaman buku perpustakaan. Berdasarkan use case tersebut dapat dilihat sistem akan memiliki 2 aktor yaitu administrator sebagai pengelola sistem dan anggota perpustakaan yang melalui aplikasi yang ada dapat melihat katalog buku serta memesan buku yang ingin dipinjam.

\section{2) Activity Diagram}

Memberikan gambaran proses atau aktivitas yang terjadi pada sistem yang akan di bangun. Gambar 5 menunjukkan Activity diagram untuk admin. Pada activity diagram admin di atas menunjukkan aktivitas yang dilakukan oleh administrator terhadap sistem yang digunakan. Pada diagram yang ditunjukkan pada gambar 5 dijelaskan secara detail tahapan aktivitas yang dilakukan oleh administrator terhadap sistem yang digunakan mulai dari menjalankan sistem, masuk atau

ISSN : 2301-7988

E-ISSN : 2581-0588

DOI : $10.32736 /$ sisfokom.v8i2.665 
login kedalam sistem, mengelola sistem sampai dengan keluar dari sistem.

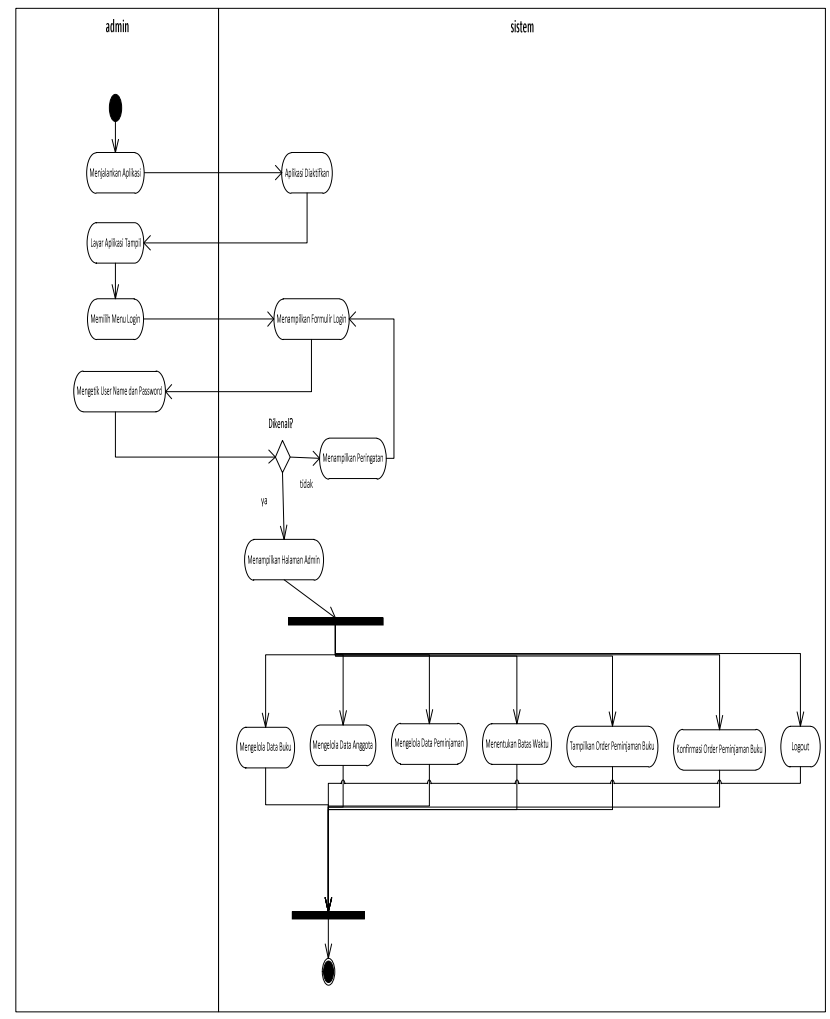

Gambar 5 Activity Diagram Admin

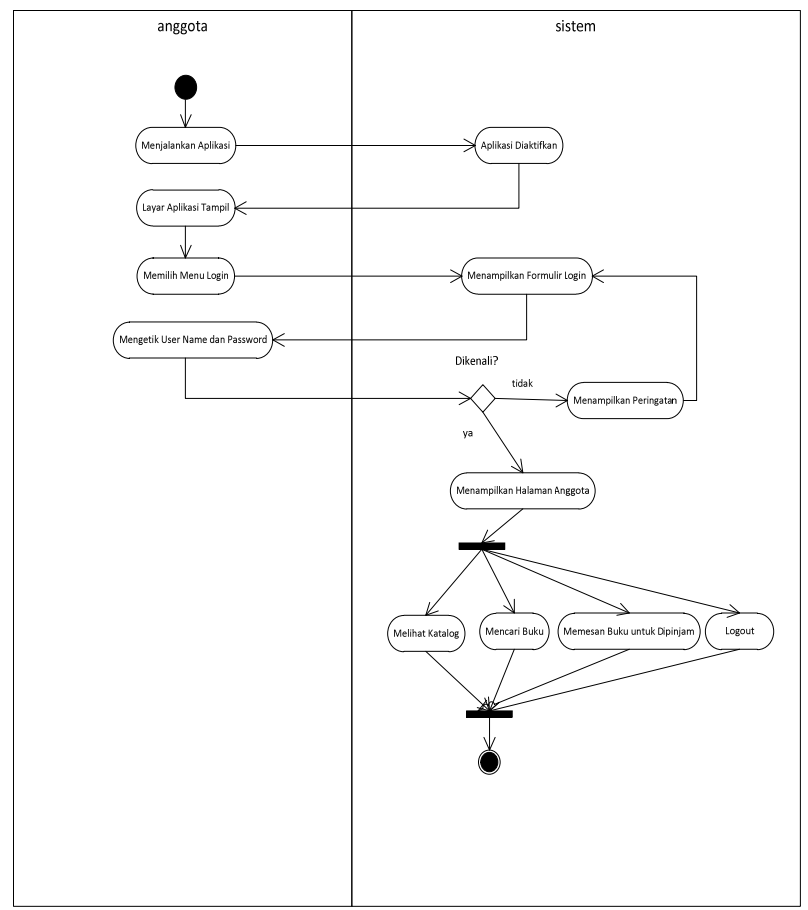

Gambar 6 Activity Diagram Angggota Perpustakaan

Gambar 6 menunjukkan activity diagram anggota dan sistem, mulai dari menjalankan sistem, login kedalam sistem, melihat katalog buku, melakukan pemesanan untuk meminjam buku perpustakaan sampai dengan keluar dari sistem.

\section{3) Class Diagram}

Digunakan untuk mengidentifikasi isi informasi yang ada pada sistem yang akan dibangun.

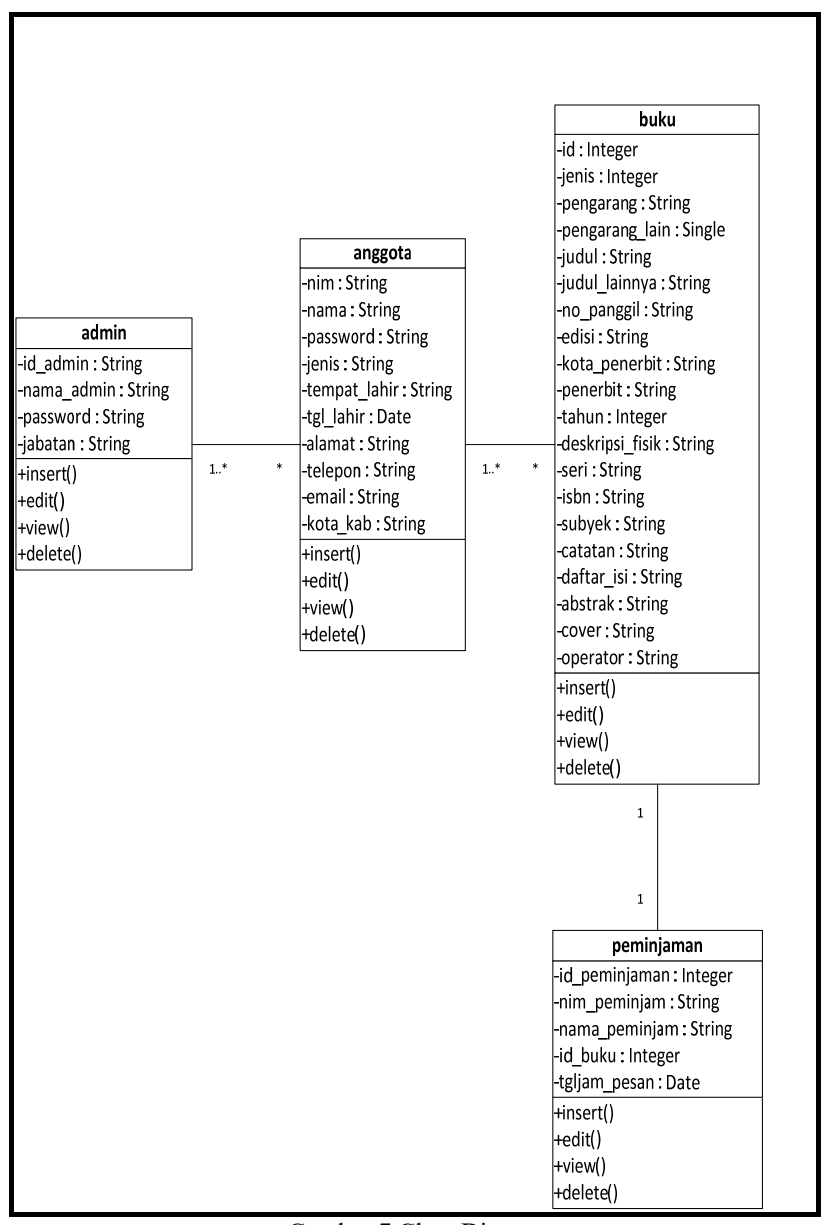

Gambar 7 Class Diagram

Class Diagram pada gambar 7 menunjukkan jumlah, nama class dan hubungannya yang harus dibuat sebagai unsur penyusun sistem. Ada 4 class lengkap dengan attributes dan method-nya. Class tersebut adalah class admin, anggota, buku, dan pinjam.

\section{B. Website Interface Design}

Website interface dirancang sebagai penghubung antara pengguna (user) dalam hal ini adalah administrator dengan Website. Website yang dibangun merupakan database server yang berintegrasi dengan aplikasi yang ada pada perangkat mobile android. Gambar 8 dan 9 merupakan beberapa tampilan antarmuka pada sisi Website. 


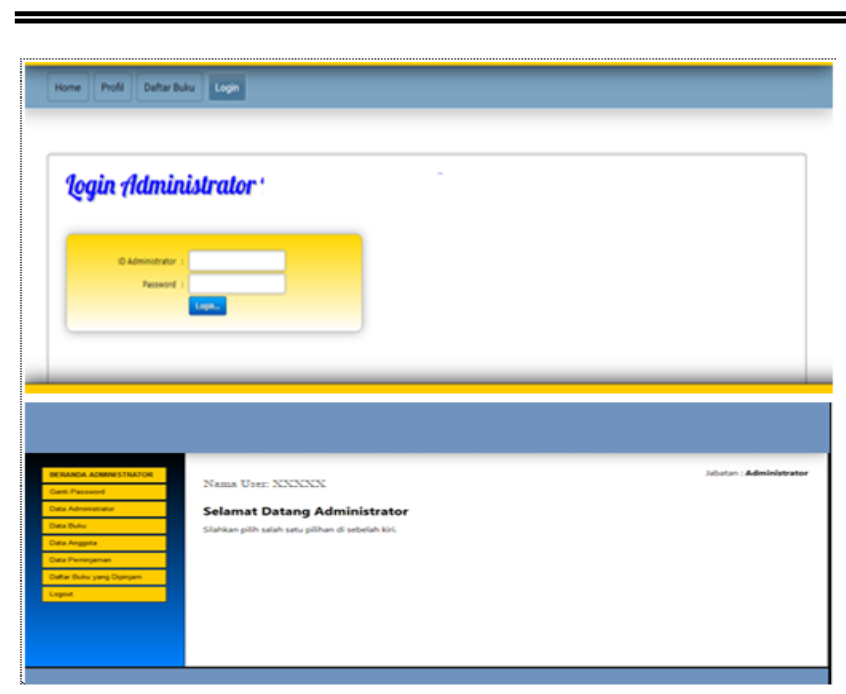

Gambar 8 Rancangan Halaman Login.

Perancangan Sistem berbasis web diperuntukakan bagi kepentingan administrator untuk memanajemen Sistem berbasis mobile android yang akan dibangun. Untuk masuk kedalam halaman administrator maka dilakukan login sebagai hak akses untuk masuk kedalam Sistem sistem e-katalog peminjaman buku perpustakaan berbasis web. Gambar 8 menunjukan rancangan halaman Login pada sisi website yang akan dibangun.

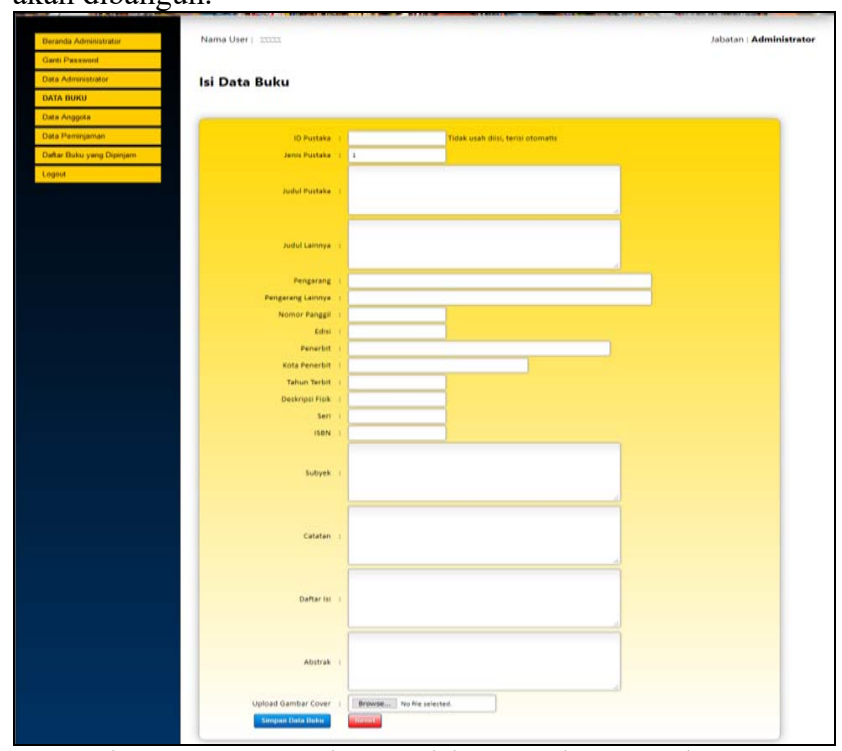

Gambar 9 Rancangan Halaman Kelola Data Buku Perpustakaan

Didalam halaman utama admin, dapat dilakukan aktivitas melakukan pengelolaan terhadap sistem. Pada Sistem yang djbangun ini admin dapat melakukan pengelolaan untuk Data admin, Data anggota perpustakaan, Data buku perpustakaan, dan data peminjaman buku perpustakaan. Gambar 9 menampilkan salah satu rancangan menu kelola data buku perpustakaan pada halaman admin.

\section{Mobile Interface Design}

Mobile interface dirancang untuk kepentingan pengguna (user) dalam hal ini adalah anggota Perpustakaan.

Gambar 10,11, dan 12 merupakan beberapa tam[pilan dashboard menu pada sistem mobile Katalog dan peminjaman buku perpustakaan.

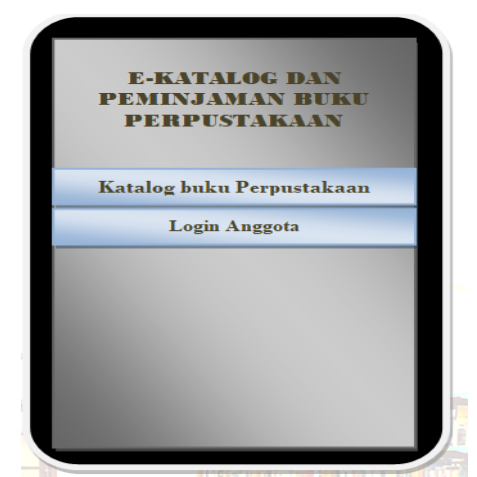

Gambar 10 Rancangan Dashboard menu sistem mobile

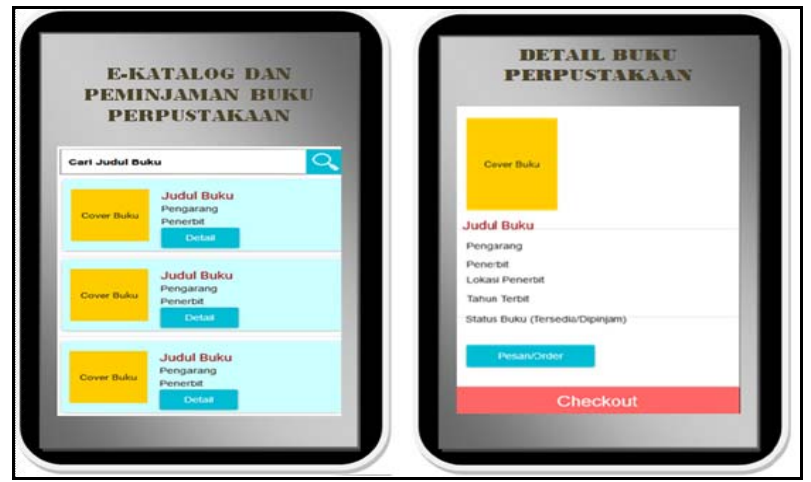

Gambar 11 Rancangan antarmuka Katalog buku perpustakaan pada sistem mobile

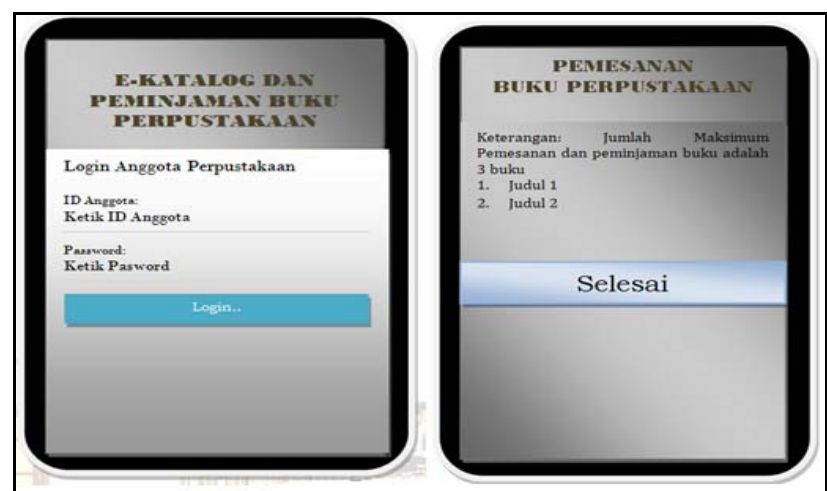

Gambar 12 Rancangan antarmuka Login pengguna pada sistem mobile

Tampilan untuk katalog dan peminjaman buku pada aplikasi mobile dapat dilihat pada gambar 13 . 


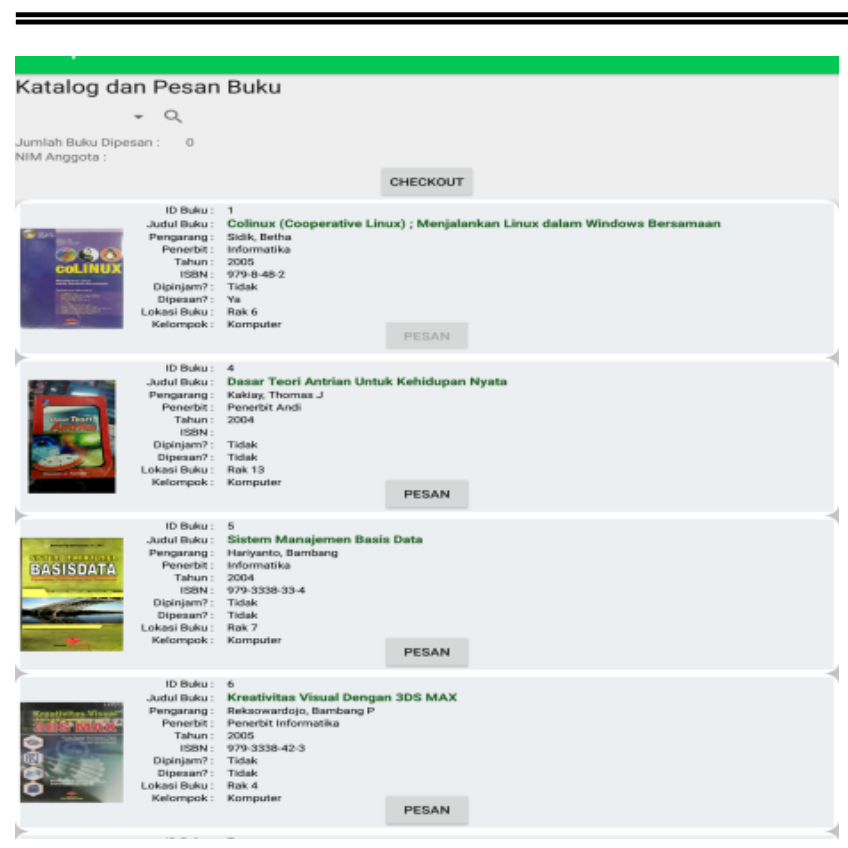

Gambar 13 Tampilan Halaman Katalog mobile

Gambar 13 menunjukkan contoh halaman katalog buku pada perpustakaan lengkap dengan informasi tentang buku serta status peminjaman buku. Selain itu dihalam ini anggota dapat melakuka pemesanan buku yang diinginkan sebelum datang ke perpustakaan.

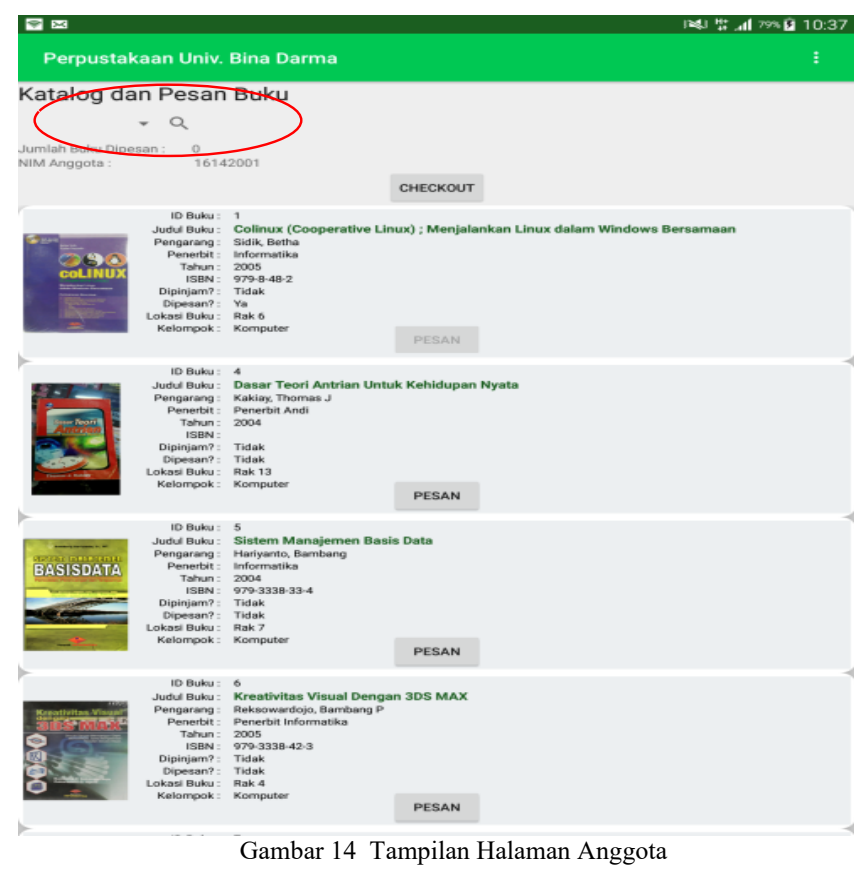

Gambar 14 menampilkan halaman katalog dan peminjaman buku bagi anggota yang sudah login. Pada halamn ini anggota dapat memilih buku yang ingin dipinjam. Sistem akan memberikan informasi jumlah buku yang dipinjam setelah anggota perpustakaan memesan buku yang mereka inginkan.

\section{PENUTUP}

Hasil Penelitian yang telah dilakukan, diperoleh rancangan sistem dan prototype e-katalog dan pemimjaman buku perpustakaan berbasis Mobile yang dapat memberikan kemudahan dalam pencarian buku pada perpustakaan serta dapat melalukan pemesanan buku yang diinginkan untuk dipinjam nantinya, terutama jika buku tersebut sulit untuk dipinjam karena jumlah yang sedikit ataupun karena banyak yang mengantri untuk meminjam. Dalam penelitian ini diperoleh rancangan sistem berupa use case diagram yang menggambarkan prilaku dari perangkat lunak ketika dibangun, Activity Diagram yang menggambarkan interaksi antara pengguna denga sistem, dan Class Diagram yang menggambarkan hubungan antar tabel atau basis data yang digunakan dalam membangun sistem. Selain itu penelitian ini juga menghasilkan desain atau rancangan antarmuka pada sisi Website yang digunakan oleh Administrator serta rancangan antarmuka baik pada sisi sisi Mobile yang akan menjadi antarmuka bagi pengguna atau (user). Selain itu hasil penelitian juga menampilkan prototype e-katalog dan peminjaman buku berbasis mobile sebagai model dalam pembangunan sistem e-katalog perpustakaan berbasis mobile.

Selanjutnya, saat sistem telah dibangun secara sempurna, perlu dilakukan tahap pengujian, baik pengujian untuk sistem ataupun pengujian dalam hal penggunaan dari sisi user (pengguna). Perlunya dilakukan pegujian, agar Sistem yang dibangun dapat berjalan dengan sempurna dan tidak lagi mengandung error sehingga dapat digunakan secara maksimal leh pengguna(user) dan dapat memberikan manfaat terutama pada kegiatan di perpustakaan

\section{REFERENSI}

[1] Indrawan, Irjus., Pengantar Manajemen Sarana dan Prasarana Sekolah. Yogyakarta: Deepublish, 2015.

[2] J Sutarno, NS., Perpustakaan dan Masyarakat. Jakarta: Sagung Seto, 2006.

[3] Trianingsih., "Peran Teknologi Informasi dalam Perpustakaan di Era Globalisasi," Makalah disampaikan pada seminar Intern Perpustakaan Universitas Atmajaya Yogyakarta, 24 Februari 2017.

[4] Supriyanto, Wahyu., Teknologi Informasi Perpustakaan. Yogyakarta: Kanisius, 2008.

[5] Safiin, Mohammad., "Aplikasi Katalog Perpustakaan STMIK AMIKOM Yogyakarta Menggunakan Mobile Berbasis Android," STMIK AMIKOM: Yogyakarta, 2013.

[6] Sulistyo, Basuki., Pengantar Ilmu Perpustakaan. Gramedia Pustaka Utama: Jakarta, 1992

[7] Asosiasi Penyelenggara Jasa Internet Indonesia., Penetrasi dan perilaku Pengguna Internet Indonesia, Jakarta: APJII, 2016.

[8] Global Stats., Operating System Market Share in Indonesia. Stat Counter, 2016.

[9] Nielsen., Millenials Are Top Smartphone Users, Nielsen Mobile Insight. The Nielsen Company. 2016.

[10] Safaat, Nazruddin., Pemrograman Aplikasi Mobile, Smartphone dan Tablet PC berbasis Android. Bandung: Informatika, 2012.

[11] Steele, J., To, N,. The Android developer's cookbook: buildinng applications with the android SDK. Pearson Education. 2010 
[12] Pressman, R.S. 2010. Software Engineering : a practitioner's approach, McGraw-Hill, New York, 68.

[13] Deppi Linda ," Merancang e-katalog berbasis Website sebagai media informasi pada Badan Perpustakaan Arsip dan Dokumentasi Daerah (BPAD," Fakultas Ilmu Komputer Informatics \& Business Institute Darmajaya, Jurnal Explore Univ. Bandara Lampung Vol 6, No 2 (2016) pp.01-11

[14] Riche Cynthia Johan," Aplikasi Mobile Perpustakaan Sekolah," Hana
Silvana dan Holin Sulistyo, Jurnal Pedagogia, Universitas Pendidikan Indomesia. Vol 14 no 3 2017. Pp 499-509

[15] Firdaus, Dwi Sakethi, dan Firdaus Rosman," Rancang Bangun Sistem Informasi Perpustakaan Berbasis Web,"jurnal komputasi Univ.Lampung Volume 3 no1 april 2015 pp94-130.

[16] T.W Oktaviani., "Perancangan User Interface berbasis Web untuk Home Automation Gateway yang berbasis IQRF TR53B," JNTETI, Vol.3 No. 3, 2015, pp. 179-186.

ISSN : $: 2301-7988$

E-ISSN : 2581-0588

DOI $: 10.32736 /$ sisfokom.v8i2.665 